\title{
GROWTH REQUIREMENTS OF THERMOPHILIC AEROBIC MICROORGANISMS IN MIXED CULTURES FOR THE TREATMENT OF STRONG WASTES
}

\author{
G. Sürücü \\ Middle East Technical University, Environmental Engineering Department. \\ 06531 Ankara, Turkey
}

\begin{abstract}
The nutritional and temperature requirements of a naturally occurring mixed culture of thermophilic microorganisms were studied. Investigations concerning the effect of temperature on the growth characteristics of the mixed culture showed that the rate of growth was highest between 55 and $58^{\circ} \mathrm{C}$. Furthermore, it was found that the minimal nutritional requirements for maximum growth of these microorganisms included methionine, magnesium, calcium, and the necessary carbon, nitrogen and phosphorus sources. It was shown that a mixed culture was nutritionally less fastidious than the pure cultures of individual organisms isolated from the mixed culture; this observation illustrated the possibility of symbiotic growth of thermophilic microorganisms insofar as meeting their individual nutritional requirements. 1999 IAWQ Published by Elsevier Science Ltd. All rights reserved
\end{abstract}

\section{KEYWORDS}

Thermophilic microorganisms; growth requirements; mixed cultures.

\section{INTRODUCTION}

Early studies on thermophilic microorganisms were limited to observations of spectacular growths in hot springs (Brock, 1967). With the remarkable progress of biochemistry, more knowledge on thermophiles has been accumulated. The literature in the area of thermobiosis, i.e., the ability of microorganisms to survive and propagate at high temperatures, has been investigated by many researchers including Singleton and Amelunxen (1973), Alfredsson et al. (1986), Bonjour and Aragno (1986), Brock (1995, 1998), Pedro et al. (1998), Fakhreddine et al. (1998), Weissmann et al. (1998), Mihovich et al. (1998), Giraffa et al. (1998), Ishida et al. (1998), and Kristjansson et al. (1985).

The investigators, who have cultured thermophilic microorganisms, generally have employed media containing complex nutrients, (Sakai et al., 1998; Mihovich et al., 1998; Giraffa et al., 1998; Kristjansson et al., 1985). Early workers made statements that the thermophilic bacteria were nutritionally fastidious and required organic nitrogen for growth (Allen, 1953). Such statements have arisen from the fact that very few thermophilic sporeformers can develop in a simple medium with ammonia nitrogen and a single carbon source. 
Work by Campbell and Williams (1953) indicated that the growth factor requirements of the thermophilic bacilli were in reality not complex and that they did not need extensive vitamin and amino acid supplements. Baker et al. (1960), after studying 26 strains of Bacillus coagulans and 68 strains of B. stearothermophilus, reported that these organisms showed four main nutritional patterns, those requiring:

a) methionine only,

b) methionine plus other metabolites,

c) methionine, but clearly stimulated by other factors, and

d) no methionine.

These observations were in general agreement with the result of Campbell and Williams (1953), and Bhat and Billimoria (1955). The former authors (Anderson and Werkman, 1949; Baker et al., 1960; Knight and Proom, 1950; Cleverdon et al., 1949) showed that the nutritional requirements for fermentation, sporulation and growth of vegetative cells for B. stearothermophilus B.dextrolactus, and B. coagulans included methionine, thiamin or riboflavin.

Fakhreddine et al. (1998), studing nine bacterial strains grown at $50^{\circ} \mathrm{C}$ on a mineral medium containing Tween 80 as sole carbon source, and Pedro et al. (1998) studying the growth requirements of Thermoccocus litoralis observed that the phase of growth had a strong influence on the types and levels of compatible solutes as culture medium. They also noted that comparatively high concentrations of solutes were required. Such a culture medium would exert a rather high osmotic pressure. This, in turn, shows that the thermophiles may be halophilic.

Studies by Pedro et al. (1998), Brock (1978) and Campbell and Williams (1953) showed that the nutritional requirements of some thermophilic microorganisms increased as the incubation temperature was increased. The reason for this was ascribed to the conditions of life at high temperatures which are more delicately balanced than at low temperatures. Thus, environmental conditions which are only slightly inhibitory to growth at ordinary temperatures can make growth impossible at 55 or $60^{\circ} \mathrm{C}$. On the other hand, under such conditions it may be necessary to provide many growth factors and building blocks for cell material. Therefore, a medium designed for optimum growth may become quite complex.

From this brief discussion, it is evident that there has been considerable investigational interest regarding the effects of environmental and nutritional factors on the growth of thermophilic microorganisms in pure cultures. However, there is a paucity of information available in the literature regarding the growth requirements of these organisms in mixed culture. Such information is of considerable interest in understanding and controlling certain microbial processes, such as the thermophilic biological treatment of wastewater containing a high concentration of organic matter, wherein heterogeneous populations rather than pure cultures are normally employed. Therefore, it was the object of this research to investigate the nutritional and temperature requirements of a naturally occurring mixed culture of aerobic thermophilic microorganisms, which might be used in treating wastewater with a high concentration of organic matter.

\section{MATERIALS AND METHODS}

\section{Culture}

A mixed culture of thermophilic organisms was established from an inoculum of soil, streamwater, raw wastewater and silage.

\section{Biological medium}

A chemically defined medium, similar to that suggested by Campbell and Williams (1953), was employed. From the literature, it can be concluded that this type of medium supports the growth of various types of thermophilic organisms. The formula of the medium is given in Table 1. 


\section{Measurement of growth}

Optical density (O.D.) measurements were employed extensively in this study in determining the concentration of organisms. O.D. determination has been recognized to be the most common and convenient method for measuring bacterial growth. A Baush \& Lomb Spectromic 20 spectrophotometer set at $660 \mathrm{~nm}$ was used in making the O.D. measurements.

Table 1. Medium used for growing thermophiles

\begin{tabular}{|c|c|c|c|}
\hline Constituent & Amount & Constituent & Amount \\
\hline L Arginine & $10.5 \mathrm{mg}$ & Nicotinic Acid & $150.0 \mu \mathrm{g}$ \\
\hline L Cystine & $4.8 \mathrm{mg}$ & Biotin & $0.9 \mu \mathrm{g}$ \\
\hline L Glutamic A. & $10.0 \mathrm{mg}$ & Folic Acid & $6.0 \mu \mathrm{g}$ \\
\hline L Histidine & $4.5 \mathrm{mg}$ & Glucose & $200.0 \mathrm{mg}$ \\
\hline L Leucine & $19.2 \mathrm{mg}$ & $\mathrm{Na}_{2} \mathrm{HPO}_{4}$ & $375.0 \mathrm{mg}$ \\
\hline L Lysine & $19.5 \mathrm{mg}$ & $\mathrm{KH}_{2} \mathrm{PO}_{4}$ & $150.0 \mathrm{mg}$ \\
\hline DL Methionine & $6.0 \mathrm{mg}$ & $\mathrm{NH}_{4} \mathrm{Cl}$ & $100.0 \mathrm{mg}$ \\
\hline L. Tryptophane & $6.0 \mathrm{mg}$ & $\mathrm{NaCl}$ & $100.0 \mathrm{mg}$ \\
\hline DL Valine & $14.4 \mathrm{mg}$ & Mineral Supp.* & $1.0 \mathrm{ml}$ \\
\hline Thiamine, $\mathrm{HCl}$ & $15.0 \mathrm{mg}$ & Dist. $\mathrm{H}_{2} \mathrm{O}$ & $100.0 \mathrm{ml}$ \\
\hline Riboflavin & $15.0 \mu \mathrm{g}$ & & \\
\hline \multicolumn{4}{|l|}{ * Mineral Supplement } \\
\hline $\mathrm{CaCl}_{2}$ & $500.0 \mathrm{mg}$ & $\mathrm{CoSO}_{4} .7 \mathrm{H}_{2} \mathrm{O}$ & $10.0 \mathrm{mg}$ \\
\hline $\mathrm{FeCl}_{3}$ & $20.0 \mathrm{mg}$ & $\mathrm{HBO}_{3}$ & $10.0 \mathrm{mg}$ \\
\hline $\mathrm{MgCl}_{2}$ & $500.0 \mathrm{mg}$ & $\left(\mathrm{NH}_{4}\right)_{6} \mathrm{Mo}_{7} \mathrm{O}_{24} \cdot 4 \mathrm{H}_{2} \mathrm{O}$ & $5.0 \mathrm{mg}$ \\
\hline $\mathrm{ZnSO}_{4} .7 \mathrm{H}_{2} \mathrm{O}$ & $100.0 \mathrm{mg}$ & $\mathrm{Na}_{3} \mathrm{VO}_{4} \cdot 16 \mathrm{H}_{2} \mathrm{O}$ & $10.0 \mathrm{mg}$ \\
\hline $\mathrm{MnSO}_{4} \cdot \mathrm{H}_{2} \mathrm{O}$ & $50.0 \mathrm{mg}$ & Dist. Water & $100.0 \mathrm{ml}$ \\
\hline $\mathrm{CuSO}_{4} .5 \mathrm{H}_{2} \mathrm{O}$ & $8.0 \mathrm{mg}$ & & \\
\hline
\end{tabular}

\section{Preparation of inocula}

In order to have a consistent inoculum (as constant as possible), the mixed culture of thermophilic organisms previously established was grown at $55^{\circ} \mathrm{C}$ in the medium described in Table 1 . The culture was aerated. When the O.D. of the cell suspension reached 0.6 , the cells were harvested by centrifugation at $5000 \mathrm{rpm}$ and $4^{\circ} \mathrm{C}$ for $10 \mathrm{~min}$. (Sorvall RC-2, Norwalk, Connecticut). The harvested cells were washed twice with a pH 7 phosphate buffer, then resuspended and adjusted to 0.05 O.D. in the same buffer. An inoculum of 0.5 $\mathrm{ml}$ of this suspension was added to $100 \mathrm{ml}$ of medium (Table 1).

\section{Experimental design}

The experimental medium (Table 1) was distributed in $100 \mathrm{ml}$ amounts into $250 \mathrm{ml}$ size containers, which were then sterilized, cooled, and inoculated with $0.5 \mathrm{ml}$ of the previously prepared cell suspension. The containers were then placed in a temperature controlled water bath where each experiment system was aerated with filtered, moisturized air. The dissolved oxygen concentration in the culture was maintained as a minimum at approximately $2 \mathrm{mg} / \mathrm{l}$.

\section{RESULTS AND DISCUSSION}

\section{Temperature effects on growth}

Batch experiments were performed at temperatures between $50^{\circ} \mathrm{C}$ and $64^{\circ} \mathrm{C}$. With the exception of the first three experiments, in which a temperature increment of $2^{\circ} \mathrm{C}$ was selected, these experiments were carried out at an increment of $1^{\circ} \mathrm{C}$. Some of the results of thirteen experiments on temperature effect are plotted in 
order to identify the maximum growth rate at the different temperatures and to emphasize more clearly the temperature effects on the growth of the mixed culture (Figure 1). The growth response at these temperatures was determined by O.D. measurements. Because of the nature of the microbial population employed, it was questioned whether changes in the predominance of the population might influence the optical measurements. Consequently, quantitative observations of the dry weight and the O.D. of the culture were made in initiating each experiment. There was no apparent difference insofar as the O.D. vs dry weight relationship was concerned. O.D. measurements were made frequently, i.e., at intervals of one or two hours following the initiation of growth, and less frequently when growth reached the stationary phase. An appreciable variation in the growth behavior of the cell population was noted. At the lower temperature, i.e., $50-55^{\circ} \mathrm{C}$ range, the growth rate was lower than those observed above $55^{\circ} \mathrm{C}$. For example, at $54^{\circ} \mathrm{C}$ (Figure 1), it took about $17.5 \mathrm{hr}$ after inoculation for the culture to reach a biomass concentration of $600 \mathrm{mg} / \mathrm{l}$ (optical density $=0.7$ ). Whereas the same concentration in microbial population was reached in $15 \mathrm{hr}$ at $57^{\circ} \mathrm{C}$ and $14.5 \mathrm{hr}$ at $58^{\circ} \mathrm{C}$. However, at lower temperatures $\left(50\right.$ to $\left.55^{\circ} \mathrm{C}\right)$, the stationary phase of growth was longer than that observed at higher temperatures. With increasing temperature, the increasing slope of the death phase of the growth curves indicates that the coefficient of decay is temperature dependent, and increases with increasing temperature (Figure 1). These observations of microbial kinetics can be explained by the Arrhenius Equation. The expression $k=A_{f} e^{-E / R T}$, which is most commonly used to quantify the effects of temperature upon reaction rates, originally was proposed for simple chemical reactions. However, within a small temperature range, this formula can be used to explain the influence of temperature on the rates of biological processes and reactions.

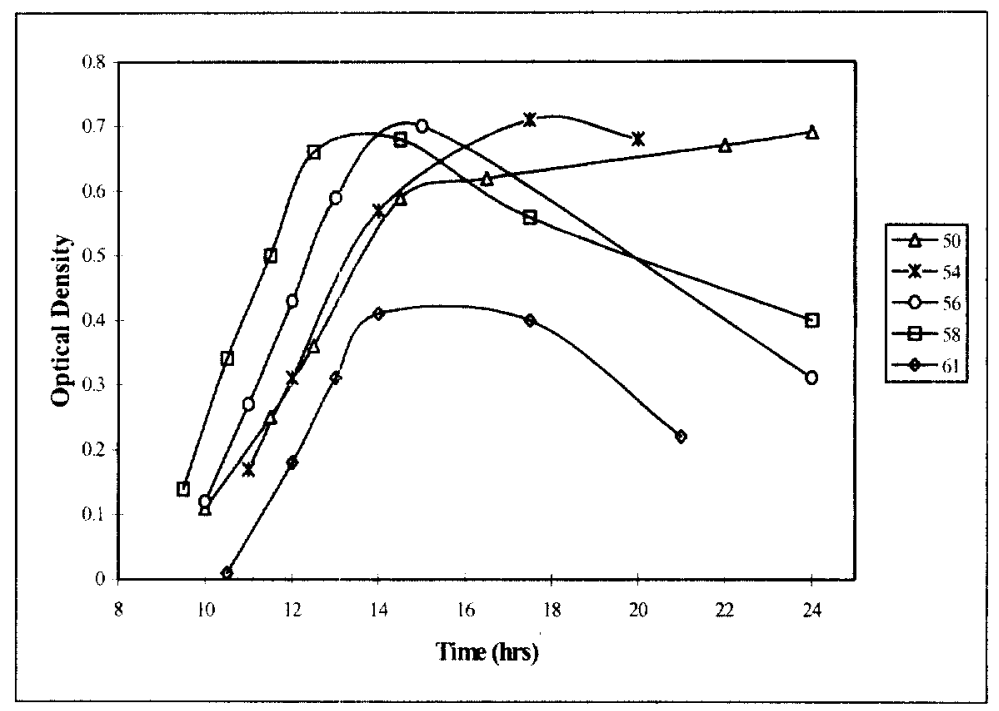

Figure 1. Temperature effects on growth.

Based upon the observations presented in Figure $1,58^{\circ} \mathrm{C}$ was chosen as the optimum temperature for the mixed thermophilic population used in this study. However, any temperature from 55 to $58^{\circ} \mathrm{C}$ could have been selected since the results in this temperature range did not differ significantly.

\section{Nutritional requirements of mixed cultures}

The results presented below are the average of those obtained in at least four, and in most cases more, separate experiments. In no case was the variation of results greater than 10 percent of the arithmetic mean. For the determination of the nutritional requirements of the mixed culture, a well defined medium (Table 1) was used. By successively eliminating individual amino acids, vitamins and minerals, one at a time, the growth characteristics of the culture in different media were studied. Furthermore, the minimal nutritional requirements of the culture was also established. The results are given in Table 4 . To show the effect of the 
more important nutrients on the growth characteristics of the culture, some of the results are plotted in Figures 2, 3 and 4 .

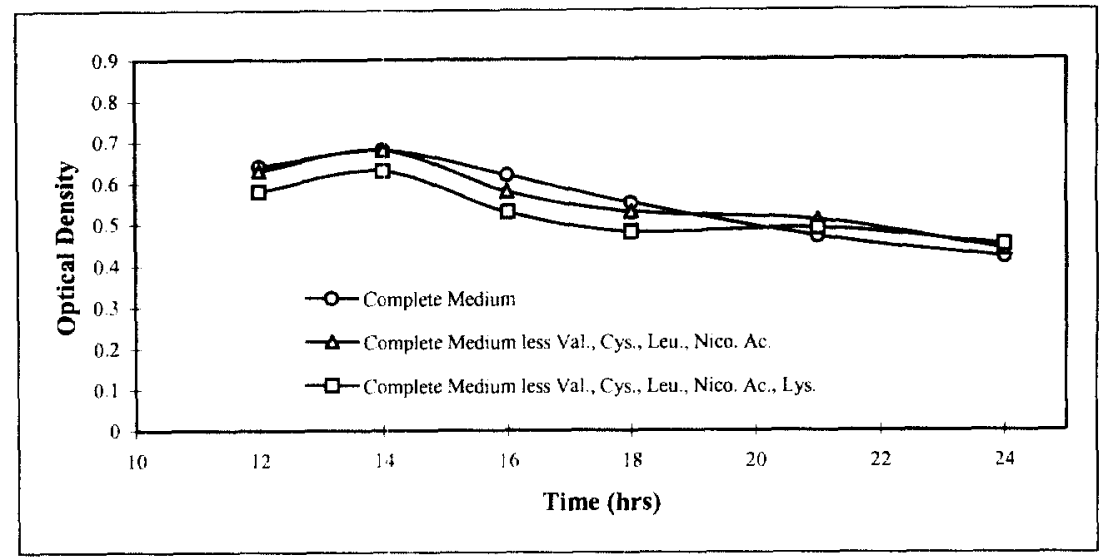

Figure 2. Nutritional requirements of thermophilic mixed culture.

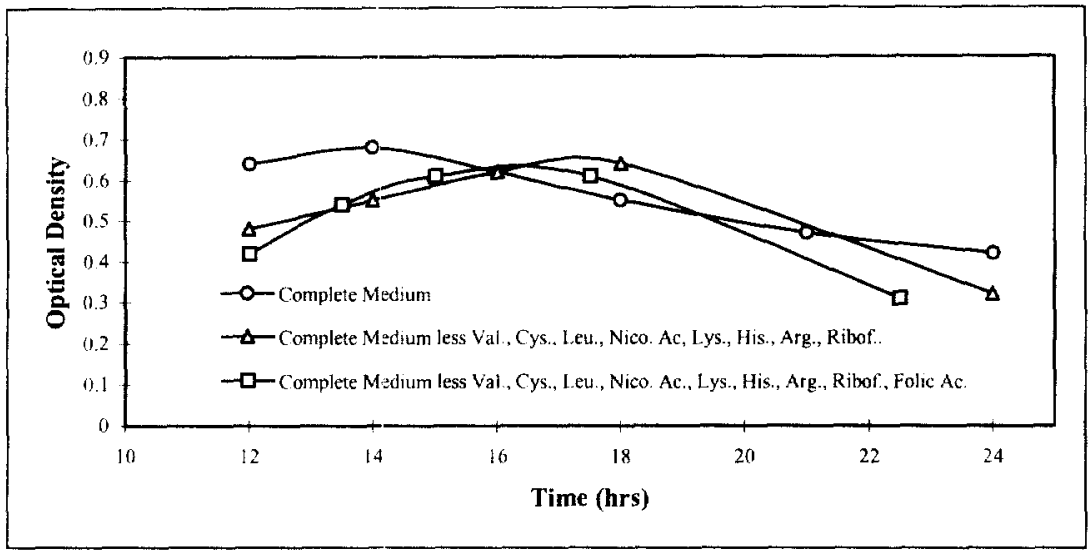

Figure 3. Nutritional requirements of thermophilic mixed culture.

Based upon the results given in Table 2, it may be noted that the elimination of the metal ions, such as cobalt, boron, molybdenum, vanadium, copper, manganese, and zinc, and the amino acids, such as valine, cystine, and leucine, did not alter the growth characteristics of the culture. As shown in Figure 2, the elimination of nicotinic acid together with valine, cystine, and leucine, did not change the general character of the growth response. Although Baker et al. (1960) reported that some of the thermophilic organisms which they isolated required nicotinic acid was not an essential vitamin for growth. Apparently, these organisms are capable of synthesizing the coenzymes involving nicotinamide adenine dinucleotide phosphate (NADP), required for the dehydrogenation reactions. Figure 2 also shows that removal of lysine together with valine, cystine, leucine and nicotinic acid from the complete medium decreased the maximum density of microorganism. This may be a sole or a collective effect of lysine. However, the decrease in cell density was not appreciable. This suggests that lysine, by itself, was not an essential amino acid but did exert a stimulating effect on the growth of the thermophilic culture.

Table 2 also indicates that the two basic amino acids, arginine and histidine, stimulated growth. The elimination of these two amino acids lengthened the time required to reach maximum growth by reducing 
the growth rate. Figure 3 shows that this shift was very significant when riboflavin (vitamin $B_{2}$ ) was further removed from the medium.

Although the biotin requirement of many thermophilic organisms has been reported frequently in the literature, the results of this study showed that biotin was not an essential vitamin. However, it was found to stimulate the growth of the mixed thermophilic culture. The same was true for folic acid, tryptophan and thiamine. However, exclusion of methionine, a sulfur containing amino acid, from the medium, caused an abrupt change in the growth characteristics of the mixed culture. There was very little growth when methionine was eliminated from the medium (Table 2 and Figure 4). This fact indicated that methionine could not be synthesized by most of the thermophilic organisms and should be added to the growth medium.

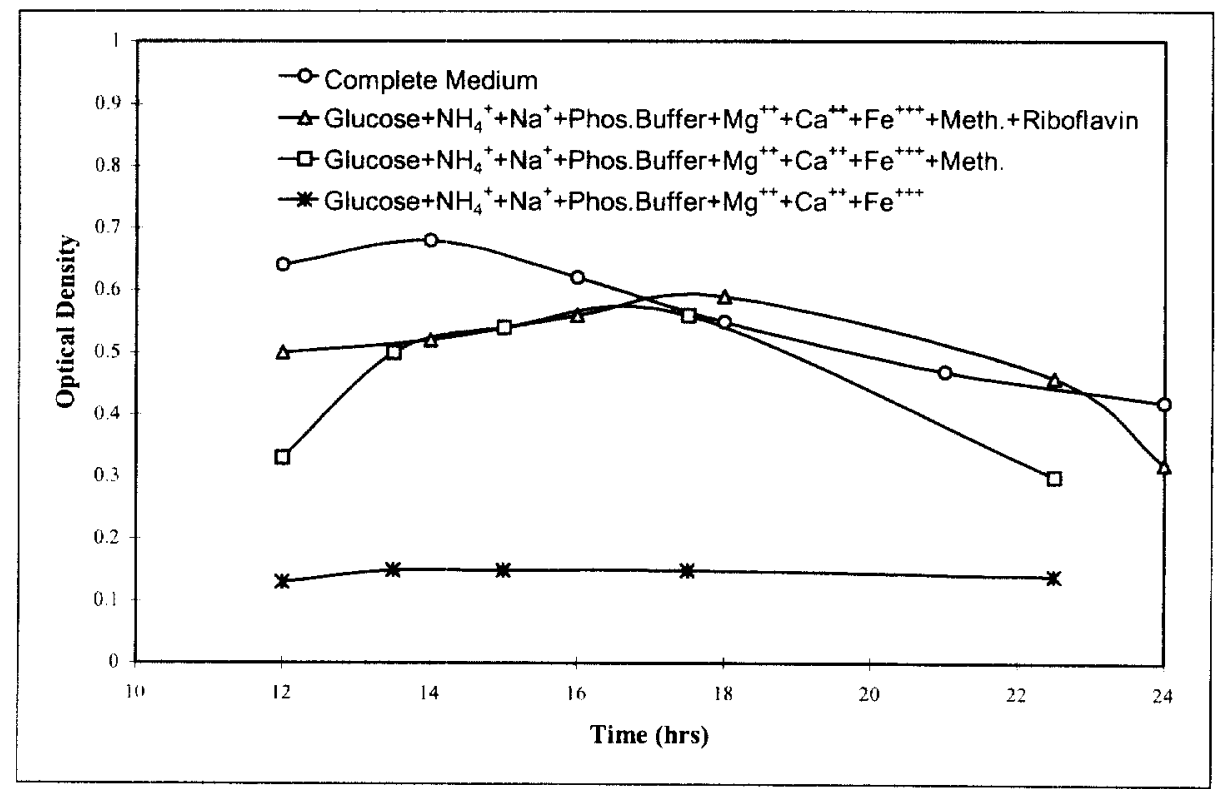

Figure 4. Nutritional requirements of thermophilic mixed culture.

Experiments on the effect of three metal ions, i.e. $\mathrm{Mg}^{++}, \mathrm{Ca}^{++}$, and $\mathrm{Fe}^{+++}$, on growth of the culture indicated a wide variation in response. In the absence of $\mathrm{Mg}^{++}$, there was essentially no growth at all. Separate elimination of $\mathrm{Ca}^{-++}$and $\mathrm{Fe}^{+++}$from the complete medium also resulted in very poor growth of the culture (Table 2).

In summary, based on the nutritional studies undertaken, methionine was found to be an essential amino acid which should be supplied to the mixed culture. Histidine, thiamine and, especially, riboflavin stimulated growth. With the elimination of $\mathrm{Mg}^{++}$from the complete medium, there was no growth. A medium which did not contain either $\mathrm{Ca}^{++}$or $\mathrm{Fe}^{+++}$produced only slight amount of growth. Based upon these observations, a minimal medium was formulated which contained glucose, methionine, riboflavine, phosphate buffer and ammonium, sodium, magnesium, calcium and ferric ions. Although the rate of growth decreased approximately 20 percent by using the minimal medium, the difference between the maximum concentration of cells resulting from using the complete and minimal media was, however, less than 0.08 O.D. units, i.e., approximately 15 percent. 
Table 2. Effect of various nutrients on growth

OPTICAL DENSITY

\begin{tabular}{|c|c|c|c|c|c|c|c|c|c|c|c|c|c|}
\hline No & $\begin{array}{l}\text { Medium } \\
\text { Composition }\end{array}$ & $\begin{array}{l}12 \\
\text { hrs }\end{array}$ & $\begin{array}{l}13.5 \\
\text { hrs } \\
\end{array}$ & $\begin{array}{l}14 \\
\text { luss }\end{array}$ & $\begin{array}{l}15 \\
\text { hrs }\end{array}$ & $\begin{array}{l}15.5 \\
\text { hrs }\end{array}$ & $\begin{array}{l}16 \\
\text { hrs }\end{array}$ & $\begin{array}{l}17.5 \\
\text { hrs }\end{array}$ & $\begin{array}{c}18 \\
\text { hrs }\end{array}$ & $\begin{array}{c}19 \\
\text { hrs }\end{array}$ & $\begin{array}{l}21 \\
\text { hrs }\end{array}$ & $\begin{array}{l}22.5 \\
\mathrm{hrs}\end{array}$ & $\begin{array}{l}24 \\
\text { hrs }\end{array}$ \\
\hline 1 & $\begin{array}{l}\text { Complete (refer to } \\
\text { Table 1) }\end{array}$ & 0.64 & & 0.68 & & & 0.62 & & 0.55 & & 0.47 & & 0.42 \\
\hline 2 & $\begin{array}{l}\text { 1-(Co, B, Mo, v, } \\
\text { Cu, Mn, Zn, Val, } \\
\text { Cys) }\end{array}$ & 0.65 & & 0.66 & & & 0.65 & & 0.53 & & 0.46 & & 0.45 \\
\hline 3 & 2-Leu & 0.64 & & 0.67 & & & 0.61 & & 0.52 & & 0.47 & & 0.43 \\
\hline 4 & 3-Nico.A. & 0.63 & & 0.68 & & & 0.58 & & 0.53 & & 0.51 & & 0.44 \\
\hline 5 & 4-Lysine & 0.58 & & 0.63 & & & 0.53 & & 0.48 & & 0.49 & & 0.45 \\
\hline 6 & 5-Histidine & 0.60 & & 0.60 & & & 0.62 & & 0.64 & & 0.58 & & 0.43 \\
\hline 7 & 6-Arginine & 0.57 & & 0.59 & & & 0.60 & & 0.63 & & 0.54 & & 0.41 \\
\hline 8 & 7-Riboflavin & 0.48 & & 0.55 & & & 0.62 & & 0.64 & & & & 0.32 \\
\hline 9 & 8-Folic A & 0.42 & 0.54 & & 0.61 & & & 0.61 & & & & 0.31 & \\
\hline 10 & 9-Biotin & 0.33 & 0.53 & & 0.57 & & & 0.58 & & & & 0.34 & \\
\hline 11 & 10-Tryp. & 0.32 & 0.52 & & 0.58 & & & 0.56 & & & & 0.31 & \\
\hline 12 & 11-Glu.A. & 0.34 & 0.55 & & 0.57 & & & 0.58 & & & & 0.29 & \\
\hline 13 & 12-Thiamine & 0.33 & 0.50 & & 0.54 & & & 0.56 & & & & 0.30 & \\
\hline $14^{*}$ & 13-Methionine & 0.13 & 0.15 & & 0.15 & & & 0.15 & & & & 0.14 & \\
\hline 15 & Complete- $\mathrm{Mg}^{+*}$ & 0 & & 0 & & & 0 & & & & & & 0 \\
\hline 16 & Complete-Fe ${ }^{i+r}$ & 0.15 & 0.20 & & 0.20 & & & & 0.20 & & & 0.21 & \\
\hline 17 & Complete- $\mathrm{Ca}^{++}$ & 0.01 & & 0.018 & & & 0.25 & & & 0.35 & & 0.49 & 0.49 \\
\hline 18 & Complete-Thia. & 0.60 & 0.67 & & & 0.69 & & 0.58 & & & & & 0.45 \\
\hline 19 & Complete-Meth. & 0.20 & & 0.23 & & & 0.25 & & 0.30 & & 0.21 & & 0.18 \\
\hline 20 & 14+Thiamine & 0.14 & & 015 & & & & 0.15 & & & & 0.15 & \\
\hline 21 & $14 \operatorname{tgu} . \mathrm{A}$ & 0.12 & & 0.14 & & & 0.18 & & 0.15 & & & 0.14 & \\
\hline 22 & 14+Thia +Meth. & 0.42 & & 0.53 & & & & 0.54 & & & & 0.39 & \\
\hline 23 & $14+$ Meth.+biotin & 0.42 & & & 0.52 & & & & & 0.47 & & & 0.32 \\
\hline 24 & 14+Meth.+flavin & 0.18 & 0.20 & & 0.20 & & & & & 0.20 & & 0.30 & \\
\hline 25 & $\begin{array}{l}\text { 14+Meth }+ \\
\text { Riboflavin }\end{array}$ & 0.50 & & 0.52 & & & 0.56 & & 0.59 & & & 0.46 & 0.32 \\
\hline
\end{tabular}

\section{CONCLUSION}

The major findings of this study may be summarized as follows:

1. The rate of growth of a mixed culture of thermophilic bacteria was maximum between 55 and $58^{\circ} \mathrm{C}$.

2. Methionine, magnesium, calcium and iron were found to be required by the mixed culture, while histidine, thiamine and, especially riboflavin stimulated growth.

3. The three dominant organisms of the culture were nutritionally more demanding in pure culture than in the mixed culture, which demonstrated a nutritional synergistic effect.

\section{REFERENCES}

Alfredsson, G. A., Ingason, A. and Kristjansson J. K. (1986). Growth of thermophilic, obligately autotrophic hydrogen-oxidizing bacteria on thiosulphate. Lett. Appl. Micrabiology 2, 21-23.

Allen, M. B. (1953). The thermophilic aerobic sporeforming bacteria. Bacterial Rev. 17, 125-173.

Andersen, A. A. and Werkman, C. H. (1949). Description of a dextrolactic acid forming organism of the genus Bacillus. Food Research, 14. 499.

Baker, H., Frank, O., Pashr, 1., Hunter, S. and Sobotka, H. (1960). Growth requirements of 94 strains of thermophilic Bacilli. Canadian Jour. of Microbial., 6, 557.

Bhat, J. V. and Billimoria, M. H. (1955). Problems in thermophily. J. Indian Inst. Sci, 37, 113.

Bonjour, F. and Aragno, M. (1986). Growth of thermophilic, obligately chemolithoautotrophic hydrogen-oxidizing bacteria related to Hydrogenobacter with thiosulfate and elemental sulfur as electron and energy source. FEMS Microbial. Letter $35,11-15$

Brock, T. D. (1967). Life at high temperatures. Science, 158, 1012.

Brock, T. D. (1995). The road to Yellowstone and beyond. Annu. Rev. Microbiology, 49, 1-28. 
Brock, T. D. (1998). Early days in Yellowstone microbiology. ASM News 64, 137-140.

Brock, T. D. (1978). Thermophilic Microorganisms and Life at High Temperatures? Springer Verlag, NewYork, NY.

Brown, C. M. (1957). Some general properties of a psychrophilic Pseudomonod. The effects of temperature on some of these properties and the utilization of glucose by this organism and Pseudomonas aeruginase. J. Gen. Microbiology, 17(3), 640 .

Campbel1, L. L. and Pace, B. (1968). Physiology of growth at high temperatures. J. Appl. Bacteriology, 31, 24-35.

Campbell, L. L. and Williams, O. B. (1953). The effect of temperature on the nutritional requirements of facultative and obligate thermophilic bacteria. J. Bact., 65, 141.

Castenholz, R. W. (1969). Thermophilic blue green algae and the thermal environment. Bacteriol. Rev., 33, $476-504$.

Cleverdon, R. C., Pelezer, M. J. and Doetsch, R. N. (1949). Vitamin requirements of B. coagulans. J. Bact., 58, 113.

Fakhreddine, L., Kademi, A., Aitabdelkader, N. and Barutti, J. C. (1998). Microbial growth and lipolytic activities of moderate thermophilic bacterial strains. Biotechnologv Letters 20(9), 879-883.

Farrel, J. and Campbell, L. L. (1969). Thermophilic bacteria and bacteriophages. Adv. Microbiol Physiol., 3(83), 109.

Farrel, J. and Rose, A. (1967). Temperature effects on microorganisms. Ann. Rev. Microbial., 21, 27-38.

Friedman, S. M. (1968). Protein synthesizing machinery of thermophilic bacteria. Bacteriol. Rev, 32, 27-38.

Gaughran, E. R. L. (1947). The thermophilic microorganisms. Bacteriol. Rev., 11, 189-225.

Girafta, G., Rosetti, L, Mucchetti, G., Addeo, F. and Neviani, E. (1998). Influence of the temperature-gradient on the growth of thermophilic Lactobacilli used as natural starters in Grana cheese. Journal of Dairy Science 81(1), 31-36.

Hanus, F. J. and Morita, R. (1966). J. Bact., 92, 1388.

Ishida, T., Hasegawa, N., Nayashi, N. R., Ishii, M., Igarashi, Y. and Kodama, T. (1997). Growth characteristics and dense culture of a thermophilic Cyanobacterium, Chroococcidiopsis sp strain Ts-821. Journal of Fermentation and Bioengineering, 83(6), 571-576.

Johnson, F. H. and Lewin, I. (1946). The growth rate of E. coli in relation to temperature, ouinine and coenzyme. J. Cellular Comparative Physiology, 28(1), 47.

Knight, B. C. and Proom, H. (1950). A comparative survey of the nutrition and physiology of mesophilic species in the genus Bacillus. J. Gen. Microbial., 4, 508.

Koffler. H. (1957). Protoplasmic differences between mesophiles and thermophiles. Bacteriol. Rev, 21, 227-240.

Kristjansson, K. J., Ingason A. and Alfredsson G. A. (1985). Isolation of thermophilic obligately autotrophic hydrogen-oxidizing bacteria, similar to Hydrogenobacter thermophilus, from Icelandic hot springs. Arch. Microbiol. 140, 321-325.

Mennet, R. H. and Nakayama, T. O. M. (1971). Influence of temperature on substrate and energy conversion in Pseudomonas fluorescens. Appl. Microbial, 22(5), 772 .

Mihovich, M. F., Brooks, B. W., Joshi, S. H. and Yamazaki, H. (1998). A liquid-medium for growth of the thermophilic Campylobacter in a carbon-dioxide air mixture as studied by polymyxin-cloth enzyme-immunoassay. Food Microbiology, 15(1), 119-125

Muck, R. E. and Grady, L. C. P. (1974). Temperature effects on microbial growth in CSTR's. ASCE Env. Engr. Div., 1147.

$\mathrm{Ng}, \mathrm{H}$., Ingrham, J. L. and Marr, A. G. (1962). Damage and depression in Escherichia coli resulting from growth at low temperatures. J. Bact, 84,331 .

Pedro, L., Martins, L. O., Da Costa, M. S. and Santos, H. (1998). Effects of temperature, salinity and medium composition on compatible solute accumulation by Thermococcus spp. Appl. Environ. Microbiol. 64, 3591-3598.

Reilly, C. T. and Sawyer, D. T. (1961). Experiments for Instrumental Methods. McGraw-Hill, 110.

Sakai, K., Yokota, A., Kurokawa, H., Wakayama, M. and Moriguchi, M. (1998). Purification and characterization of three thermostable endochitinases of a noble bacillus strain, MH-1, isolated from chitin-containing compost. Appl. Environ. Microbiol., 64(9), 3397-3402.

Singleton, R. Jr. and Amelunxen, R. E. (1973). Proteins from thermophilic microorganisms. Bacteriol. Rev, 37, 320-342.

Thimann, K. V. (1963). The Life of Bacteria, $2^{\text {nd }}$ Ed. The McMillan Co., NY.

Weisman J. C., Radway J. C., Wilde, E. W. and Benemann, J. R. (1998). Growth and production of thermophilic Cyanobacteria in a simulated thermal mitigation process. Bioresource Technology 65(1-2), 87-95. 